\title{
TRIANGULATING SOME DISCOURSE-RELATED ISSUES IN INDONESIAN EFL PRE-SERVICE TEACHERS' WRITTEN NARRATIVES
}

\author{
Joseph Ernest Mambu \\ Satya Wacana Christian University, Indonesia
}

\begin{abstract}
This paper attempts to document how the notion of discourse was made sense of by EFL teachers from the U.S.A. and by me as an Indonesian who read and commented on 16 narratives written by four male and four female pre-service/student teachers. While the Americans tended to focus on the superficial content and textual organizations, I have found it crucial to appreciate the themes, styles, and philosophies these pre-service teachers presented in their narratives. First, the themes were clustered, thus showing how one pedagogical story relates to or differs from another. Second, the styles of arranging thoughts indicate how Indonesian teachers in this study were overall more indirect so the American readers assumed more responsibility to decipher their implied meanings. From my perspective, however, the salient discourse style is that of philosophizing. In essence, the philosophies in several narratives reflect traces of the ongoing process of believing what these teachers did or practiced as prospective teachers or as colleagues.
\end{abstract}

Key words: pre-service teachers, narrative, discourse, philosophizing

A bulk of teachers' narratives reflecting on the experiences of language teaching and learning experiences has been documented (Johnson \& Golombek, 2002). However, a lot more stories from the teaching practicum setting, especially in response to Shi's (2002: 149) call for documenting ESL/EFL preservice teachers' narratives, will further enrich the variety of narratives in terms of lengths, themes or "thematisation" (cf. Brown \& Yule, 1983: 133-152), and styles (how these narratives are structured by narrators).

With regard to styles, some scholars have made cross-cultural comparisons between essays produced by a certain group of people (usually of a country) and those by another group. The most common dichotomy for comparison 
is that of western vs. non-western writing style. According to Kaplan (1966), western authors are more straightforward in expressing their intentions than their non-western counterparts, including Indonesians. This tendency is concurrent with Hinds (1987) who posits that western people require more responsibility from writers to make their writings as lucid as possible for readers. On the other hand, non-western writers tend to pass the responsibility to the readers to make sense of their (elusive) writings.

Comparing written or spoken narratives, in particular, styles have also been examined. Tannen (2007), citing her earlier study in 1982, asked her students to record informal conversations in which they were involved, then select a story from the conversations. After that the person who told the story orally to the student was asked to write it down. While the vast majority of the written stories typically belonged to the written "expository prose" style, one written story evinced the features (i.e., the "involvement strategies") that characterized a spoken/oral/conversational style (p. 29). Involvement indicates a "joint production of meaning" between an author/speaker and a listener/audience/reader (p. 28). She further explains that involvement strategies work on two levels: "on the one hand, sound and rhythm, and on the other, meaning through mutual participation in sensemaking" (p. 30). This study was limited to the meaning level.

With regard to meaning, involvement strategies include "indirectness [or conveying unstated meaning], ...tropes [or figures of speech], ... [constructed] dialogue [or what others have said], ...imagery and detail, and ...narrative" (Tannen, 2007: 32, 37-39), among others. There is actually one more involvement strategy which constitutes another focus of my analysis: "philosophizing", which may somehow fit Tannen's notion of detail. The idea of philosophizing in a narrative derives from Tannen's (1980) study in which she compared narrative discourse of two groups: Greek and American young women. Having watched a movie, they were asked to retell the movie. It turned out, however, that the way the Americans organized their narratives differed from those of the Greeks. Whereas the Americans tended to recount as many details in the movie as they could memorize (with some comments on technical elements of the movie and its production), the Greeks were more inclined to philosophize (or to evaluate, in Labov's [1972] formulation) its message and judged the behaviors of its characters. Whether such involvement strategies typical in spoken discourse apply in narratives written by Indonesians has yet to be confirmed (despite empirical evidence showing the traces of oral tradition 
in some Indonesian students' undergraduate theses in Makassar, South Sulawesi; see Jubhari, 2008, for instance).

It will be too ambitious to trace all of the reviewed involvement strategies. Hence, of salience in this present study is, first, to chart the themes of the collected narratives. Second, it is important to know how the American readers view the teachers' narrative discourse in general and the (in)directness of the narratives in particular. Third, teachers' philosophizing capacity as an involvement strategy deserves to be appreciated in its own right; otherwise, the pedagogical values/beliefs/voices embedded in their narratives - no matter how explicit they are - will go unnoticed or undervalued, at worst.

\section{METHOD}

Data of eight (out of 18) English Department of Satya Wacana Christian University (SWCU) student (pre-service) teachers who had completed their teaching practicum were analyzed in the present study. Four male and four female students' TOEFL scores by the time of data collection were above 500 . For the sake of anonymity, the male students were coded M1, M2, M3 and M4 and the female students F1, F2, F3, and F4. All other names (of schools, teachers, lecturers, and friends) in their stories were also pseudonyms. They were chosen due to their GPAs, TOEFL scores, previous stay in an English-speaking country, and the complexity of their narratives (which surpassed the other narratives written by the other 10 students whose essays had initially been collected). The data show that, M2's and M3's scores were 600 plus. M3 was one of the best graduates. M4 used to live in the United States for some time as his father worked there. While the four female student teachers, M1 and M4 are Javanese by ethnicity, M2 and M3 are Indonesian-born Chinese. They were in their early twenties and were in their final year in the SWCU undergraduate program of TEFL. All of them had just completed their teaching practicum course in some secondary schools in Salatiga.

Based on the stories, it becomes apparent that they taught in four schools: "W" School (done by F3); "X" School (M1 and M4); "Y" School (F1, M2, and M3); and "Z" School (F2 and F4).

Triangulation of data was made possible by the assistance of three American colleagues teaching in ED-SWCU: (1) AT (a B.A. holder, in his midthirties), (2) RK (an M.A. holder, in her fifties), and Vic (an M.A. holder, in his 
late twenties). The lengths of stay in Indonesia vary from more than 20 years (RK), seven years (AT), to three years (Vic) - as of August 2008.

Sixteen narratives (eight "good" and eight "bad" stories) were elicited from eight students last January 2007. The students were asked to write their "good" and "bad" personal experiences during the teaching practicum s/he had just completed on a piece paper with time limit (maximum of 45 minutes). Each narrative was supposed to be written in at least 300 words in English. It turned out that the total number of words was 6,931 (with an average of 433.175 words per narrative per person). The pre-service teachers, however, were told that they could switch to Indonesian in their writing when they found it too difficult to express an idea in English.

Data were then triangulated by AT, RK, Vic, and myself. First, they were asked to pinpoint any interesting features in the narratives that were typically Indonesian with regards to discourse (e.g., the way the students organized the narratives). I did not specifically exemplify philosophizing as a way of structuring some thoughts in narrative discourse to my American colleagues. There was no time limitation for them to comment on the essays but they were returned in two weeks. Finally, I analyzed the narratives in light of Tannen's $(1980,2007)$ notion of involvement strategies in general and philosophizing in particular.

\section{FINDINGS}

There are nine themes, consisting of five "good" themes and four "bad" themes. The "good" themes are (1) an enjoyable teaching experience (M4 and F1), (2) an awful teaching preparation which turned into a positive experience (F3), and memorable experiences with (3) students (M1 and M2), (4) fellow student teachers (M3), and (5) a teacher or "guru pamong" at school (F2 and F4). The "bad" themes range from (1) unpleasant moments in the first teaching experience to conflicts with (2) teachers (M1 and F1), (3) fellow student teachers (M2, M3, F2, and F4), and (4) a student (F3).

The Americans did not address such a thematization. They were concerned with the contents superficially (table 1) or in a critical (especially faultfinding) way (table 2). The number of praises and criticisms is significantly imbalanced, with the latter being more dominant. Some criticisms were harsh (e.g., Vic's comments on F1's verbosity and RK's inability to make sense M2's last four sentences of his bad experience). Some other criticisms required more 
writers' responsibility to be comprehensive (e.g., Vic's demand for F3 to explain why "everything changed") and incoherence (e.g., AT's spotting an inconsistency in F1's story).

\section{Table 1. Praises on Contents}

\begin{tabular}{cclc}
\hline No & Praises on & Comments & $\begin{array}{c}\text { Readers }- \text { Commented } \\
\text { student teachers }- \\
\text { Commented stories (G/B) }\end{array}$ \\
\hline 1 & Introduction & $\begin{array}{l}\text { This is the standard intro taught } \\
\text { in Amer. composition. }\end{array}$ & Vic-M1-B \\
2 & Conclusion & Nice conclusion & Vic-M1-G \\
\hline
\end{tabular}

Note: $\mathrm{G}=\mathrm{a}$ "good" experience ; $\mathrm{B}=\mathrm{a}$ "bad experience"

Table 2. Criticisms on Contents

\begin{tabular}{|c|c|c|c|}
\hline No & Criticisms on & Comments & $\begin{array}{c}\text { Readers - commented } \\
\text { student teachers - } \\
\text { commented stories } \\
(\mathrm{G} / \mathrm{B})\end{array}$ \\
\hline \multirow[t]{6}{*}{1} & $\begin{array}{l}\text { Comprehensive } \\
\text { ness }\end{array}$ & $\begin{array}{l}\text { (a) Content could be more developed } \\
\text { (b) Ideas could be elaborated on } \\
\text { better; }\end{array}$ & $\begin{array}{l}\text { AT-M4-B } \\
\text { AT-M4-G }\end{array}$ \\
\hline & & $\begin{array}{l}\text { (c) I would emphasize the setting of } \\
\text { the events to create a better } \\
\text { picture. }\end{array}$ & Vic-M2-G \\
\hline & & (d) Conclusion feels week. & Vic-M2-B \\
\hline & & $\begin{array}{l}\text { (e) The two events of this essay need } \\
\text { to be contrasted more explicitly. }\end{array}$ & Vic-M3-G \\
\hline & & $\begin{array}{l}\text { (f) The org. is fine but the details } \\
\text { should be filled in. }\end{array}$ & Vic-M4-G \\
\hline & & $\begin{array}{l}\text { (g) On a whole text level, I'm not } \\
\text { quite clear about where the } \\
\text { offense came from. It seems a } \\
\text { small thing to develop the whole } \\
\text { essay around. }\end{array}$ & Vic-F1-B \\
\hline
\end{tabular}


66 TEFLIN Journal, Volume 20, Number 1, February 2009

\begin{tabular}{|c|c|c|c|}
\hline \multicolumn{4}{|c|}{ Table continued } \\
\hline \multirow{4}{*}{2} & \multirow{5}{*}{ Verbosity } & $\begin{array}{l}\text { (h) Whole text level: why is this the } \\
\text { "good" experience? She says } \\
\text { "everything changed" but doesn't } \\
\text { explain. }\end{array}$ & Vic-F3-G \\
\hline & & $\begin{array}{l}\text { (a) This was already established in } \\
\text { the previous paragraph. }\end{array}$ & AT-F2-G \\
\hline & & $\begin{array}{l}\text { (b) same opening (as the bad } \\
\text { experience) }\end{array}$ & Vic-M4-G \\
\hline & & $\begin{array}{l}\text { (c) I would cut the introduction for } \\
\text { both these essays. }\end{array}$ & Vic-F2-G \\
\hline & & (d) repetition (of the bad experience) & Vic-M4-G \\
\hline \multirow{4}{*}{3} & \multirow{4}{*}{ Incoherence } & (e) On a whole text level, I'm not & Vic-F1-B \\
\hline & & $\begin{array}{l}\text { (a) "making friends offers many } \\
\text { chances" } \rightarrow \text { isn't the lesson more } \\
\text { about being diligent and self- } \\
\text { motivated? }\end{array}$ & AT-F4-G \\
\hline & & $\begin{array}{l}\text { (b) F1: }{ }^{30} \text { Then, I leaned lazily against } \\
\text { the wall when I responsed to her } \\
\text { questions. }{ }^{31} \text { I didn't feel } \\
\text { comfortable with this situation. } \\
{ }^{32} \text { I felt that her question were out } \\
\text { of border since she was my } \\
\text { school teacher at this time. } \\
{ }^{33} \text { Thus, since I was very curious } \\
\text { to what she thought }[\ldots] \rightarrow \text { AT: } \\
\text { [Sentence } 33] \text { conflicts with } \\
\text { previous sentence. }\end{array}$ & AT-F1-B \\
\hline & & $\begin{array}{l}\text { (b) F1: }{ }^{30} \text { Then, I leaned lazily against } \\
\text { the wall when I responsed to her } \\
\text { questions. }{ }^{31} \text { I didn't feel } \\
\text { comfortable with this situation. } \\
{ }^{32} \text { I felt that her question were out } \\
\text { of border since she was my } \\
\text { school teacher at this time. } \\
{ }^{33} \text { Thus, since I was very curious } \\
\text { to what she thought }[\ldots] \rightarrow \text { AT: } \\
\text { [Sentence } 33] \text { conflicts with } \\
\text { previous sentence. }\end{array}$ & AT-F1-B \\
\hline
\end{tabular}




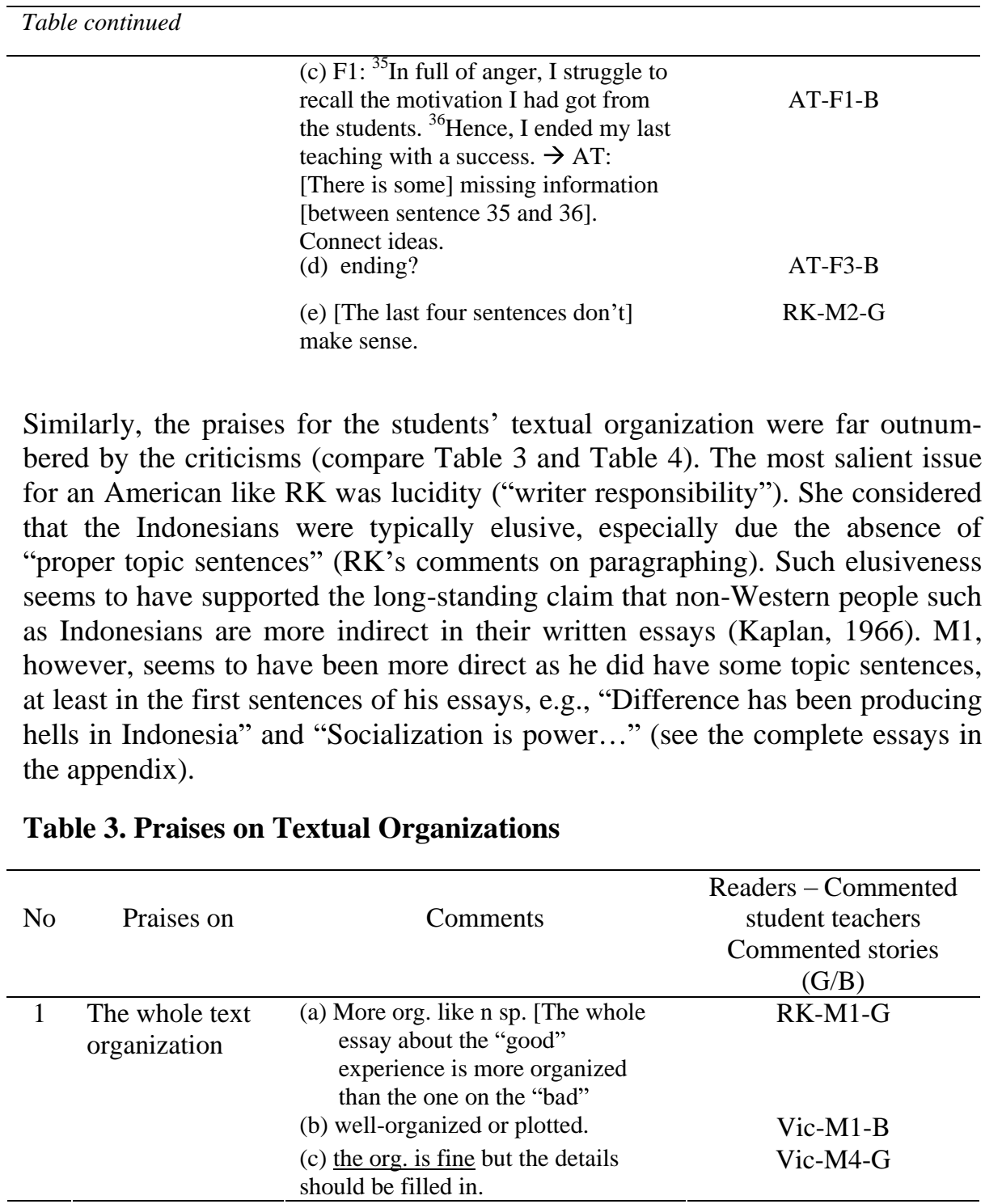


Table 4. Criticisms on Textual Organizations

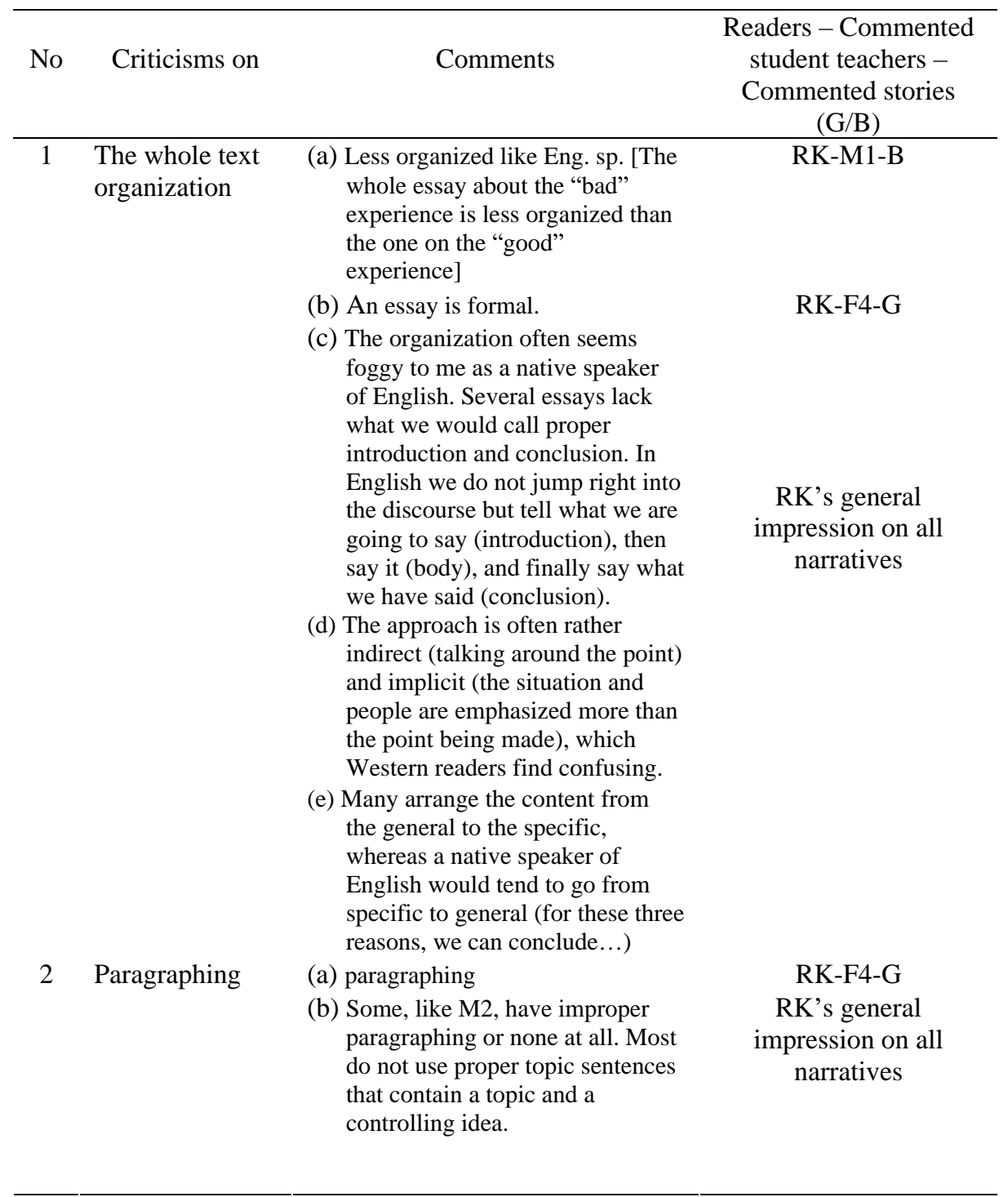




\begin{tabular}{|c|c|c|}
\hline Table continued & & \\
\hline 3 "Punchlining" & $\begin{array}{l}{ }^{18} \text { No matter how smart and high your } \\
\text { GPA if you don't want to open mind } \\
\text { and learn from someone better than } \\
\text { you, you'll be nothing } \rightarrow \text { Vic: I } \\
\text { would save general conclusion for the } \\
\text { end. }\end{array}$ & Vic-F4-G \\
\hline
\end{tabular}

Furthermore, the three Americans did not seem to agree with each other on individual cases, as far as their written comments on discourse are concerned. For instance, only Vic and AT who agreed that M4 should have elaborated on the details of his story about a good experience (see Table 2 concerning comprehensiveness). What may be qualitatively implied, however, suggests another picture. From the written comments, it can be implied that at least Vic and RK considered that M1's essays were relatively more 'well-written', and 'nativelike ${ }^{1}$, than those of other teachers (see Tables 1 and 3). Scrutinizing the individual cases again, however, Vic and RK did not entirely agree to each other. While Vic regarded M1's introductory paragraph of his bad experience as "the standard intro taught in Amer. composition" (see table 1) and the whole paragraph as "well-organized or plotted" (see Table 3), RK thought that the same story was "less organized" (Table 4). Moreover, AT did not give as many comments on discourse as RK and Vic.

These differences suggest that a total dependence on American EFL teachers' written feedback on essays by Indonesian teachers (will) distort the bigger picture: not only does the performed language (especially on the discourse level) matter but also the substances these Indonesian teachers brought to the fore through their writings. In essence, the substances of these teachers' narrative discourses are contextually, intertextually, and philosophically shaped. They are located within personal and social spaces. The personal space provides rooms for teachers to contest pedagogical ideas/theories/philosophies and feelings. The social space is where an EFL (pre-service) teacher interacts with school stakeholders and attempts to position her-/himself at a distance or

1 Following Cameron and Low (1999), I use these conventions: single inverted commas (e.g., 'error'), indicating a degree of distancing by me, and double inverted commas (e.g., "errors") denoting a quotation or my personal voice (p. ix). 
in concert with these stakeholders. Therefore, the ways an individual teacher positions her-/himself within a learning community as reflected in her/his theme of (narrative) discourse deserve much more attention, which is lacking in the three Americans' feedbacks on discourse.

Apart from distinct involvement strategies (i.e., 'direct' vs. 'indirect'/'elusive' style) between the Americans and the Indonesians, the themes warrant further attentions. In this analysis, in particular, I am indebted to Tannen's (1980) notion of philosophizing as an evaluative device (cf. Labov, 1972) in a storytelling event. Some of the examples have been shown in Table 5 (see also the complete narrative in the appendix) where philosophical-sounding noun phrases were repeatedly used by M1 to highlight his philosophical theme that evinced his vehement opposition to his mentor: "The tiring of difference day" and "not in the same principle". At the first mention of the phrase "The tiring of difference day", both AT and RK underlined the phrase, indicating their confusion about its meaning. Vic seemed to suspend his judgment (by not underlying it) but then with his "intersubjectivity" (i.e., his attempt to make sense of M1's implied intention or to understand where M1 was coming from; see Larsen-Freeman, 2003, p. 45), he polished the phrase in the $53^{\text {rd }}$ sentence of the same narrative into "with a tiring day of personal differences". A similar intersubjectivity was exhibited by AT who changed the preposition "in" into "of" in the phrase "not in the same principle". This polishing act is, in my opinion, different from 'error' correction as it is the Americans' attempts to enhance the intelligibility of M1's expressions.

Table 5. The Philosophical Tendency

\begin{tabular}{|c|c|c|c|c|}
\hline No & $\begin{array}{c}\text { Pre- } \\
\text { service } \\
\text { teachers }\end{array}$ & $\begin{array}{c}\text { Frequency - story type - sentence } \\
\text { numbers - examples }\end{array}$ & $\begin{array}{l}\text { triangulated by ( } \& \\
\text { corrections/comme } \\
\text { nts) }\end{array}$ & $\begin{array}{l}\text { quantitatively } \\
\text { confirmed by } \\
\text { (\& frequency) }\end{array}$ \\
\hline 1 & M1 & $\begin{array}{l}\text { 4: (a) B-title: The tiring of difference } \\
\text { day; (b) B-53: The tiring of difference } \\
\text { day; (c) B-7: In Bahasa Indonesia, there } \\
\text { is a slight different between 'not in the } \\
\text { same principle' (ketidaksepahaman) and } \\
\text { misunderstanding (kesalahpahaman); (d) } \\
\text { B-8: When I did my PPL in "X" School } \\
\text { Salatiga, I experienced difference by } \\
\text { being 'not in the same principle' }\end{array}$ & $\begin{array}{l}\text { (a) AT: [wavy line + } \\
\text { ?]; RK: [underlined]; } \\
\text { (b) AT: [wavy line + } \\
\text { ?] RK: [underlined]; } \\
\text { Vic: with a tiring day } \\
\text { of personal } \\
\text { differences; (c) \& (d) } \\
\text { AT: in } \square \text { of [not of } \\
\text { the same principle] }\end{array}$ & $\begin{array}{l}\text { Note: (a) \& (b) } \\
\square \text { triangulated } \\
\text { by AT, RK, and } \\
\text { Vic; (c) and (d) } \\
\square \text { by AT only }\end{array}$ \\
\hline
\end{tabular}


In fact, M1's introductory paragraph is full of philosophizing phenomena (see the complete narrative in the appendix). He started with a topic sentence with the topic being "difference" and the controlling idea being "producing hells in Indonesia". This theme is intertextually linked to various current issues in Indonesia: GAM (Aceh Movement for Independence), riots in Poso (Sulawesi), and a war in Sampit (Kalimantan). The idea of literal killing in various places in Indonesia due to "difference" was then narrowed down to the figurative killing toward M1 by his mentor. In fact, not only was Vic as an American impressed by this paragraph (see Table 1 above), but also M1's discourse here confirms Becker's (1979) contention (as cited in Johnstone, 2003, p. 642) that the sense of coherence in Javanese shadow puppet is built up by way of "spatial coincidence", not of a chronological order (as in the 'western' writing style). In subsequent paragraphs M1 structured his narrative chronologically but in the first paragraph he expanded the space from that of his experience as a preservice teacher in a school to other killings taking place in some areas in Indonesia.

M1 (A bad experience)

${ }^{1}$ Difference has been producing hells in Indonesia. ${ }^{2 a}$ The hells include separatism movement in Aceh, known as GAM (Gerakan Aceh Merdeka); ${ }^{2 b}$ Poso riots in which three unguilty people were sentenced to death; ${ }^{2 \mathrm{c}}$ war in Sampit in which human lost their humanity by killing other humans by cutting their heads; ${ }^{2 \mathrm{~d}}$ and many other hells that need more than one book to write on. ${ }^{3}$ People say that difference is usual and needed. ${ }^{4}$ As for me, they are true, but actually difference has 2 sides. ${ }^{5}$ The positive side is when we can tolerate difference and, hereby, we can live together in perfect harmony. ${ }^{6}$ The negative side is when we cannot tolerate difference. ${ }^{7}$ In Bahasa Indonesia, there is a slight different between 'not in the same principle' (ketidaksepahaman) and misunderstanding (kesalahpahaman). ${ }^{8}$ When I did my PPL [teaching practicum] in " $X$ " School Salatiga, I experienced difference by being "not in the same principle', and, therefore, I faced the negative side of difference. ${ }^{9}$ This experience (being different from my guru pamong) is a really tiring job.

In M1's next narrative (a good experience - see the appendix), philosophizing phenomena also transpired. His discourse style (or involvement strategy) was of a more direct one. This 'violates' the common expectation that Indonesian ('non-western') writers are typically elusive. RK attested to the "more 
organized" essay (see Table 3). The echoing voice of his father "Socialization is power" set the tone for the rest of M1's story. The exact wording was even repeated (sentences 6,17 ), rephrased as "I found the meaning of socialization" in sentence 43, and made more salient in other repetitive phrases "make/made/ making [many] friends" (sentence 2, 4, 9, 25, and 42). Thus, philosophizing is interweaved through alluding to another's (M1's father's) voice that is intertextually shaped in the storytelling event as a new context which is then reinforced through repetition. As Becker (1995) puts it, as cited in Tannen (2007):

Languaging can be understood as taking old texts from memory and reshaping them into present contexts. (9)... "All languaging is what in Java is called jarwa dhosok, taking old language (jarwa) and pushing (dhosok) it into new contexts" (185). (p. 11, italics original)

M1's father's voice became the "jarwa" being pushed in a new context where M1 did his teaching practice. Concerning M1's repetitive phrases, in particular, it may be the case that M1, either as a Javanese by ethnicity himself or as an individual irrespective of ethnicity, possesses a repeating strategy that coincides with Becker's (1984) observation as cited in Tannen (2007): "repeating strategies... in a wayang drama are characteristic of a Javanese aesthetic of density" (p. 85). M1's story was indeed dense with the main theme: socialization with students.

M1's narrative is exemplary and yet he is not the only teacher with a philosophizing capacity. Here are some other examples from four more preservice teachers that are relevant to language pedagogy and interpersonal relationships among teachers (Notes: [a] words in square parentheses were supplied by the Americans to enhance clarity; [b] the underlined parts indicate my impression about their philosophizing capacity no matter how trivial they may seem):

\section{F1 (A good experience)}

[...] ${ }^{16}$ I thought since the students were like noise, then I had to create a meaningful noise also when they doing the activities. ${ }^{17}$ Yet, I assumed that the students were actually brilliant students. ${ }^{18}$ At that time, I realized that every activity that would be done by the students had to relate with students' background knowledge. ${ }^{19}$ Besides, as a teacher I have to regard the students as human that full of amazing ideas. ${ }^{20}$ That thinking had me success mend- 
ing a relationship [succeed in establishing a relationship] with the students. [...]

\section{F2 (A good experience)}

[... ${ }^{28}$ She kept giving my suggestion about my teaching everytime I did the consultation. ${ }^{29}$ And she was different from other guru pamong. ${ }^{30} \mathrm{Bu}$ Elly never gave suggestion like that. ${ }^{31}$ And the other guru pamong never gave the student teacher nice comments about the teaching. ${ }^{32}$ While bu betty, even she gave a bad comments, she always mengimbanginya [balanced them] with a nice comments that wont make her student teacher got down. ${ }^{33} \mathrm{In}$ fact, her student teacher will be more semangat [motivated] to do the next teaching.

\section{F4 (A bad experience)}

[...] ${ }^{29}$ Overall, she taught me something to sharpen my personality trait to become wiser and more patient. ${ }^{30}$ Thank you... .

\section{F4 (A good experience)}

[...] ${ }^{31}$ So, what I got from this story was making friends offers many chances. ${ }^{32}$ Chance for me to develop my capability, to enrich my creativity and to deal with something bad/wrong and good.

\section{M3 (A bad experience)}

[... ${ }^{38}$ That incident taught me something after all: that I have to be more patient. ${ }^{39}$ Those unnecessary questions are meant to show kindness, to build the connection. ${ }^{40}$ They are not merely stupid things with no meanings. ${ }^{41}$ Thus, that bad incident with Robert really gave me something to apply in my life.

\section{M3 (A good experience)}

[... ${ }^{29}$ So, if I have to choose with whom I want to work in a group, I would still say that I would prefer my closest friends who I have really known already. ${ }^{30}$ It's not because of collusion. ${ }^{31}$ It's not because I'm underestimating others. ${ }^{32}$ Then, it's also not about someone else's capability. ${ }^{33 a}$ It's about people who I have known well; ${ }^{33 b}$ those who I understood more 
than anyone else, vice versa. ${ }^{34}$ When I am in a group of that kind of people, I feel more comfortable to finish my works.

When it came to a real teaching experience, some pre-service teachers might not have remembered teaching theories they learned prior to or concurrently with the teaching practicum. Reflecting on her teaching experience, for instance, F1 came up with the idea of relating class activities to students' background knowledge.

The other stories (F2, F4, and M3) are more interpersonal than pedagogical. This, however, does not make the themes trivial or absolutely nonpedagogical. Rather, the ways pre-service teachers philosophized the mentor's assessment style (in F2's story) and built their relationships with fellow preservice teachers (in F4's and M3's stories) are of equal importance to teachers' decision to plan their lessons (as in F1's story). As an old adage says "experience is a good teacher", these teachers' pedagogical and personal experiences affected their teaching practices as a whole. By reflecting on their practices through the written narratives, these teachers will inform such teacherresearchers like me of what have happened in language classrooms in a more systematic way no matter how subjective or anecdotal each story appears. I predict that, until a teacher's subjectivity in a story is triangulated by a lot of similar stories, a more objective inter-subjectivity will in turn be attained.

\section{DISCUSSION}

It is high time to offer a sound counter-standpoint toward the mainstream view in the EFL teaching that favors the 'native-like' illusion, especially in regard to discourse style, (sub)consciously perpetuated by many EFL teachers. Such a mainstream view may especially be espoused by EFL teachers from - to use Kachru's (1989) term as cited in McKay (2002, pp. 6-9) - Inner Circle countries. According to the three Americans participating in this study, for instance, the narrative (discourse) style of the eight pre-service teachers is, on the whole, indirect and requires reader's responsibility to make sense of the story contents. From my perspective as an Indonesian, we need to push our thinking beyond the Americans' tendency to look at the weaknesses of the narrative essays written by some Indonesians in terms of contents and textual organizations. In view of the most current debate on Englishes, I concur with. 
Pennycook (2007) who contends that:

The crucial point here... is not so much whether or not one is born in a particular type of community but rather what one does with the language. It is in the performance that the identity is created. (p. 35)

Some traces of the pre-service teachers performances using Englishes are indeed reflected in the way they make meaning and construct their thoughts through narrative essays. It may be misleading, therefore, to think that the discourse style of a community (e.g. Indonesian pre-service teachers) is preemptively determined by where the members of community are born. A dichotomy on identity like 'western' vs. 'non-western' may be useful for an entry point of locating where a certain discourse style is typically used. In fact, this has been somewhat confirmed by the general trend that Indonesian writers in this study are more indirect. Nonetheless, as these writers might have been exposed to people from other countries or to academic writings, their performance - that is, how they go about the language in their writings - complicates the picture. M1, for instance, interweaved both indirectness (e.g., allusions to various current events in Indonesia in his first paragraph) and directness (e.g., the use of topic sentences in some of his paragraphs; see the appendix).

The nine themes generated in this study are certainly non-exhaustive. In essence, it can be projected that by collecting more stories from pre-service teachers, we will be in a better position to delve into pre-service teachers' sense of achievement and failures in their teaching practicum more systematically. Embedded in the stories with various themes are how teachers not only made sense of events and characters with whom they interacted but also reflected specifically on their pedagogical beliefs (or philosophies).

These teachers' philosophizing voices - which are typically located near or at the end of their narratives - may be overlooked if discourse analysts are too much concerned with grammatical accuracies at the morpho-syntactical level and broad textual organizations. Part of inquiring into at least these teachers' discourse (in their personalized English[es]) is listening to their struggles and philosophically reflected solutions within their pedagogical and interpersonal contexts in Indonesia, particularly in Salatiga.

In spite of the limited number of stories as only sixteen pre-service teachers' narratives were analyzed, I contend that this study has been a preliminary attempt to respond to Kleinsasser's (1993) call for documenting sto- 
ries that foster a nonroutine school culture where teachers can exchange their valuable teaching and interpersonal experiences and beliefs or philosophies (cf. Sato \& Kleinsasser, 2004) significant for their professional development as prospective EFL teachers in Indonesia. A special attention has been paid to those stories told in Englishes which are pregnant with an array of 'elusive' meanings to be deciphered by EFL teachers from Inner Circle and Expanding Circle countries (cf. McKay, 2002) alike.

\section{CONCLUSION AND SUGGESTION}

At the discourse level, I have the impression that on the whole the Americans (especially RK) with their writer-responsibility expectation and 'straightforwardness' imposed on the Indonesians have not sufficiently appreciated the Indonesian teachers' philosophizing capacities as learners (and prospective EFL teachers) whose English has been personalized owing to (a) their Indonesian as L1, (b) the contexts of the stories that revolve around experiences during teaching practicum in Indonesia, and (c) the storytelling event that was not framed in a gate-keeping encounter as they knew their narratives would not be influencing their grades. Inspired by Labov's (1972) notion of evaluation and Tannen's (1980)'s observation on a philosophizing inclination as an evaluative device, I find the teachers' some philosophical contributions to the professional development in the foreign language pedagogy in Indonesia. More importantly, the philosophizing capacity is a discourse style in its own right that EFL teachers should attend to more thoroughly. Hence, this study attempts to push our thinking beyond the 'direct'-'indirectness' divide (as somewhat perpetuated by RK representing a horde of like-minded EFL teachers worldwide).

To follow up this research, I recommend that more narratives be elicited from more pre-service teachers in such non-gatekeeping situations as replicating the procedure of collecting written essays or where pre-service teachers can interact directly to advanced English speakers (regardless of their origins) orally in a friendly setting. The scope may also extend to the Labovian evaluative devices or Tannen's (2007) involvement strategies other than that of philosophizing, which have yet to be adequately addressed here. In terms of data triangulation, further inquiries should be directed to including a more refined framework for analyzing discourses that goes beyond discrediting EFL (preservice) teachers' discourse styles/strategies of using personalized English(es) as shown in this study. The framework (e.g., Tannen's involvement strategies) 
is to accommodate and appreciate these teachers' discourse styles (e.g., philosophizing) and their pedagogical voices (e.g., F1's decision to relate class activities to students' background knowledge).

\section{REFERENCES}

Brown, G., \& Yule, G. 1983. Discourse Analysis. Cambridge: Cambridge University Press.

Cameron, L., \& Low, G. (Eds). 1999. Researching and Applying Metaphor. Cambridge: Cambridge University Press.

Hinds, J. 1987. Reader Versus Writer Responsibility: A New Typology. In U. Connor \& R. Kaplan (Eds), Writing Across Languages: Analysis of L2 Text (pp. 141-152). Reading, MA: Addison-Wesley.

Johnson, K. E., \& Golombek, P. R. (Eds). 2002. Teachers' Narrative Inquiry as Professional Development. Cambridge: Cambridge University Press.

Johnstone, B. 2003. Discourse Analysis and Narrative. In D. Schiffrin, D. Tannen \& H. E. Hamilton (Eds), The Handbook of Discourse Analysis (pp. 635-649). Malden, MA: Blackwell Publishing.

Jubhari, R. 2008. Traces of Indonesian Oral Tradition in Skripsi. Paper presented at the 6th AsiaTEFL International Conference, Sanur, Bali, Indonesia.

Kaplan, R. 1966. Cultural Thought Patterns in Inter-Cultural Education. Language Learning, 16, 1-20.

Kleinsasser, R. C. 1993. A Tale of Two Technical Cultures: Foreign Language Teaching. Teaching and Teacher Education an International Journal of Research and Studies, 9(4), 373-383.

Labov, W. 1972. The Transformation of Experience in Narrative Syntax. In W. Labov (Ed.), Language in the Inner City (pp. 352-396). Philadelphia, PA: University of Pennsylvania.

Larsen-Freeman, D. 2003. Teaching Language: From Grammar to Grammaring. Boston, MA: Thomson Heinle. 
McKay, S. L. 2002. Teaching English as an International Language. Oxford: Oxford University Press.

Pennycook, A. 2007. Global Englishes and transcultural flows. London and New York: Routledge.

Sato, K., \& Kleinsasser, R. C. 2004. Beliefs, Practices, and Interactions of Teachers in a Japanese High School English Department. Teaching and Teacher Education, 20(8):797-816.

Shi, L. 2002. A Tale of Names. In K. E. Johnson \& P. R. Golombek (Eds), Teachers' Narrative Inquiry as Professional Development (pp. 136-149). Cambridge: Cambridge University Press.

Tannen, D. 1980. A Comparative Analysis of Oral Narrative Strategies: Athenian Greek and American English. In W. L. Chafe (Ed), The Pear Stories: Cognitive, Cultural, and Linguistic Aspects of Narrative Production (pp. 51-88). Norwood, New Jersey: ABLEX Publishing Corporation.

Tannen, D. 1982. Oral and Literate Strategies in Spoken and Written Narratives. Language, 58(1):1-21.

Tannen, D. 2007. Talking Voices: Repetition, Dialogue, and Imagery in Conversational Discourse (2nd ed.). Cambridge: Cambridge University Press. 


\section{Appendix. M1's narratives.}

\section{Bad Experience}

\section{"THE TIRING OF DIFFERENCE DAY"}

${ }^{1}$ Difference has been producing hells in Indonesia. ${ }^{2 a}$ The hells include separatism movement in Aceh, known as GAM (Gerakan Aceh Merdeka); ${ }^{2 \mathrm{~b}}$ Poso riots in which three unguilty people were sentenced to death; ${ }^{2 \mathrm{c}}$ war in Sampit in which human lost their humanity by killing other humans by cutting their heads; ${ }^{2 \mathrm{~d}}$ and many other hells that need more than one book to write on. ${ }^{3}$ People say that difference is usual and needed. ${ }^{4}$ As for me, they are true, but actually difference has 2 sides. ${ }^{5}$ The positive side is when we can tolerate difference and, hereby, we can live together in perfect harmony. ${ }^{6}$ The negative side is when we cannot tolerate difference. ${ }^{7}$ In Bahasa Indonesia, there is a slight different between 'not in the same principle' (ketidaksepahaman) and misunderstanding (kesalahpahaman). ${ }^{8}$ When I did my PPL in " $X$ " School Salatiga, I experienced difference by being 'not in the same principle', and, therefore, I faced the negative side of difference. ${ }^{9}$ This experience (being different from my guru pamong) is a really tiring job.

${ }^{10}$ On Monday, Mrs. Dinda (my guru pamong) told me that on Saturday (on

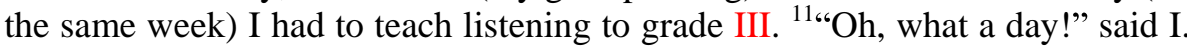
${ }^{12}$ "I have to be a speaker in PPL seminar also on that day." ${ }^{13}$ It means that I had to prepare 2 things: mentality and the materials of both jobs. ${ }^{14} \mathrm{I}$ had to teach listening at 07.00 a.m to $08.30 \mathrm{am}$ whereas I had to be the speaker at 08.45 a.m.. ${ }^{15 a}$ My guru pamong did not seem to be interested with my problem; ${ }^{15 b} \mathrm{I}$ had to teach.

${ }^{16}$ Considering that problem, I decided to work on my listening materials on Thursday, so that on Friday, I could concentrate on seminar preparation. ${ }^{17}$ Starting on Wednesday, I looked for materials, such as book and so on. ${ }^{18} \mathrm{I}$ got a really well-planned and good idea about what I would teach. ${ }^{19}$ I would gave a recording (consisting of 3 paragraphs) about "Bermuda Triangle", followed by 5 essay questions. ${ }^{20}$ One of the questions is that $I$ asked students to look at America map that was provided and look for as well as draw the location of "Bermuda Triangle". 
${ }^{21}$ “"This must be interesting for students," I talked to myself. ${ }^{22}$ I also provided a recording of a song, titled "Greatest love of all" by Whitney Houston. ${ }^{23}$ I planned to ask students to fill the missing words. ${ }^{24} \mathrm{After}$ finding the materials, I worked on it. ${ }^{25} \mathrm{I}$ made up the questions and lesson plan. ${ }^{26} \mathrm{All}$ of these stuffs finished on Thursday at 07.00 p.m. ${ }^{27}$ I started to create the recording with my colleague, Doni, in my boarding house. ${ }^{28}$ I saved my work in computer and planned to record it into cassette on Friday at 10.00 a.m. because it had been 11.00 p.m.

${ }^{29}$ On Friday morning at 08.00 a.m., I went to "X" School to consult my lesson plan to Mrs. Dinda. ${ }^{30}$ She looked unsatisfied while looking and reading my lesson plan. ${ }^{31}$ Her eyebrows went down with a scary eyes shinning unhappy look.

32،"This is not what I want. ${ }^{33}$ You should make another one," said Mrs. Dinda, ${ }^{34 a \text { a } I}$ want you to make questions like TOEFL test; ${ }^{34 \mathrm{~b}}$ one question is followed by 4 answer choices."

35a،"Why din't you tell me since Monday?" ${ }^{35 b}$ I talked to myself, because I did not dare to challenge her.

36، You can use your materials for grade II, but not for grade III because grade III are focused on Final Exam. ${ }^{37}$ Hereby, they have to be trained the same question type as Final Exam," she explained.

38،"This is what I'm doing," said I.

${ }^{39}$ "No, you are not," she cut my point, ${ }^{40}$ "You have to teach them tomorrow morning with different recording."

${ }^{41}$ After saying that, she went away to class. ${ }^{42}$ I went to my boarding house and called Doni whether he could save me from this misery or not.

${ }^{43}$ Finally, on Friday, I worked on the materials once more, from 01.00 p.m. to $05.00 \mathrm{p} . \mathrm{m}$. ${ }^{44}$ Iwan came late to my boarding house, making me angry by letting me wait for a long time. ${ }^{45}$ While waiting for him, I created an outline of what I should say on PPL seminar held just 15 minutes after I finished listening class. ${ }^{46}$ Doni and I finished creating new recording at midnight.

${ }^{47}$ I woke up at 06.00 a.m. on Saturday. ${ }^{48}$ I practised my PPL seminar outline for a while and then went to "X" School by foot because the transportation was always full at that hour. ${ }^{49} \mathrm{I}$ just taught my new materials (one question followed by four multiple choice answers) and went at $08.15 \mathrm{a} . \mathrm{m}$. without telling Mrs. Dinda. ${ }^{50}$ I left the students for another 15 minutes because I had to go to campus to prepare PPL seminar. 
${ }^{51}$ After the seminar had finished, I took a deep breath and talked to myself, "I will never ever want to do this kind of heck and work with the same person anymore. ${ }^{52}$ This is tiring." ${ }^{53}$ I prayed to God for helping me in the tiring of dif-

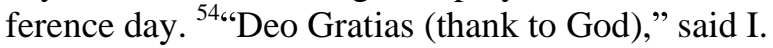

\section{Good experience}

\section{MAKING FRIENDS IS A VALUABLE ASSET}

"'Socialization is power", this saying, said by my father, echoed on my ears when Mrs. Rani (dosen pembimbing PPL), my friends and I started PPL program in "X" School Salatiga. ${ }^{2}$ My father is a social person, successful on making many friends. ${ }^{3} \mathrm{My}$ father says that neighbours, brothers who live far away, all people are to a valuable asset for us to succeed. ${ }^{4}$ As for me, according to my father, I am such a shy person. ${ }^{5} \mathrm{I}$ do not think so because I think the matter is my father has much more friends than I do. ${ }^{6} \mathrm{I}$ admit that actually at that time I had not know what my father meant by "socialization is power". ${ }^{7} \mathrm{At}$ PPL, I found what he meant by proving it. ${ }^{8} \mathrm{I}$ made friends with one student that introduced me to other ones and helps me in my teaching. ${ }^{9} \mathrm{By}$ now, I admit that making friends is a valuable asset for me to succeed.

${ }^{10}$ On Saturday, all PPL teachers including me, gathered in office for that was office day. ${ }^{11} \mathrm{I}$ saw Prakoso shonning plain eyes and listening to music. ${ }^{12} \mathrm{I}$ saw Dita, Puspita, and Yunus talking to each other. ${ }^{13 a}$ I found myself thinking what I should do to make my PPL teaching successful whereas I was obliged to teach grade III; ${ }^{13 b}$ the grade which are mature enough to think critically towards what I teach and easy enough to get bored towards how I teach and clever enough to play tricks on me.

${ }^{14}$ "Kriing...," the bell rang, it was break time, students were coming out of the class to go to café ${ }^{15}$ I saw my PPL friends still doing the same things. ${ }^{16} \mathrm{I}$ stood up, looking at students gathering in café.

${ }^{17}$ "Socialization is power," this words came up to my mind. ${ }^{18} \mathrm{I}$ encouraged myself to go to face and sat down in a table with 2 boy students. ${ }^{19} \mathrm{I}$ introduced my name to them. ${ }^{20}$ They are Boy and Radit. ${ }^{21 a}$ We talked about our hobies, activities and many fun things; ${ }^{21 \mathrm{~b}}$ except things that can lead to anger. ${ }^{22}$ After breaktime finished, I went back to the office. ${ }^{23}$ This time I found my friends looking at me with fury. ${ }^{24}$ "What were you doing?" said one of them.

${ }^{25}$ "Just making friends," I answered. 
${ }^{26}$ When it was time to leave school, Boy surprisingly appeared in front of me.

27،"Mas, would you join OSIS having fun activity in Sekar Langit?” Boy offered me something that I wait. ${ }^{28}$ I agreed. ${ }^{29}$ That day, I went home accompanied by Boy with his motorcycle.

${ }^{30}$ The day of OSIS activity came. ${ }^{31}$ Boy picked me up to " $X$ " School. ${ }^{32} \mathrm{He}$ introduced me to many other students and teachers who also participate in OSIS activity. ${ }^{33}$ I thought that it was the starting point of my success in PPL. ${ }^{34}$ OSIS went to Sekar Langit waterfall, a place near Kopeng. ${ }^{35}$ The committee went there by motorcycle, including me and Boy. ${ }^{36}$ The leader of the committee asked me to help the committee. ${ }^{37}$ Students and I had fun, and joy in togetherness.

${ }^{38}$ On the next day, when it was time to do my first teaching, I noticed that I know some of my students and vice versa. ${ }^{39} \mathrm{We}$ knew each other in OSIS activity. ${ }^{40}$ This made me more relaxed, confident and, hereby, enjoy my teaching. ${ }^{41}$ At break time, we hang out together in café. ${ }^{42}$ I made friends with much more students.

${ }^{43}$ While my PPL friends were busy with their other PPL friends, I found the meaning of socialization. ${ }^{44}$ I knew who my students are and they knew who I am and, hereby, we enjoyed teaching learning process. ${ }^{45}$ Prakoso was still listening to music. ${ }^{46}$ Dita and Puspita were still talking each other. ${ }^{47 a}$ I found myself different: ${ }^{47 b}$ I found an asset to succeed in PPL by making friends. 